\title{
Terveys on onnistuneen kotoutumisen edellytys
}

Vuonna 2017 julkaistun Yhdistyneiden kansakuntien Maahanmuuttoraportin mukaan muualla kuin syntymämaassaan asuvista 258 miljoonasta henkilöstä 78 miljoona asui Euroopan maissa (1). Vaikka suurin osa kansainvälisestä muuttoliikkeestä tapahtuu naapurimaiden välillä, maahanmuutto alhaisen- ja keskitulotason maista Eurooppaan on kasvanut merkittävästi viime vuosikymmenten aikana. Maahanmuuttosyyt vaihtelevat: jotkut muuttavat työn tai paremman elämän perässä, toiset pakenevat luonnonkatastrofeja, köyhyyttä, konfliktia, epäinhimillistä kohtelua tai sotaa.

Kansainvälisessä maahanmuutossa on valtavasti potentiaalia väestörakenteeltaan ikääntyvän Euroopan taloudelliselle kasvulle ja kehitykselle koska selvä enemmistö tänne muuttavista henkilöistä on työikäisiä. On kuitenkin tärkeää tiedostaa, että maahanmuuton hyödyt voidaan saavuttaa ainoastaan vaikuttavien kotoutumistoimien kautta.

Työllisyyttä käytetään keskeisenä kotoutumisen indikaattorina. Ulkomaalaistaustaisen väestön terveys ja hyvinvointi jäävät usein vähemmälle huomiolle, vaikka nämä ovat keskeisiä osallisuuden ja kotoutumisen edellytyksiä. Kuten tuoreessa Maailman Terveysjärjestön pakolaisten ja siirtolaisten terveyttä käsittelevä raporttissa esitetään, ei ole kansanterveyttä jos ei huomioida pakolaisten- ja ulkomaalaistaustaisen väestön terveyttä (2). Yhteiskunnan yhdenvertaisena, aktiivisena ja vastavuoroisena jäsenenä toimiminen edellyttää riittävää fyysistä-, psyykkistäja sosiaalista toimintakykyä.

Terveys on geneettisen perimän ja ympäristön vuorovaikutuksen tulos. Siihen vaikuttavat myös erilaiset altistukset koko elämänkulun aikana. Vaikka geneettinen perimä altistaa sairauksille, ympäristöllä on keskeinen rooli geenien toiminnan säätelyssä. Krooniset sairaudet syntyvät useimmiten elämänkulun aikana toistuvien altistusten seurauksena (3). Altistusten vaikutuksen arvioidaan olevan erityisen merkittävä, jos se tapahtuu tiettyjen sikiö-, lapsuus- ja aikuisiän herkkyyskausien aikana. Jotkut altistukset voivat tapahtua satunnaisesti, mutta toistuvat negatiiviset altistukset useimmiten kasautuvat tietyissä väestöryhmissä. Sosiaaliset rakenteet, kuten sosiaalinen ja poliittinen ympäristö, määrittelevät toistuvien altistusten kasautumisen todennäköisyyttä.

Ulkomaalaistaustaisen väestön geneettinen alttius sekä ennen maahanmuuttoa koettujen altistusten laatu ja vakavuus saattavat poiketa merkittävästi maahanmuuttomaan väestön alttiuksista ja altistuksista. Keskeisiä altistuksia ennen maahanmuuttoa voivat olla esimerkiksi infektiosairaudet, heikot elinolot, heikko hygienia ja ravitsemus sekä epävakaa poliittinen tilanne. Sen lisäksi, että itse maahanmuuttoprosessi ja matka ovat hyvin kuormittavia henkisesti, ne saattavat olla myös hengenvaarallisia tai altistaa myös vakaville tapaturmille. Maahanmuuton jälkeisiä altistuksia ovat esimerkiksi heikot terveystiedot ja heikko terveyspalveluiden saatavuus tai saavutettavuus, ympäristöön liittyvät muutokset terveystottumuksissa sekä rakenteellinen ja sisäistetty rasismi.

Väestön terveystarkastustutkimuksia on toteutettu säännöllisin välein Suomessa jo 1950-luvulta lähtien. Terveystarkastustutkimuksilla on ollut keskeinen rooli alueellisten ja sosioekonomisten terveyserojen kaventamisessa. Suomen väestö on ollut hyvin homogeeninen 1990-luvun asti, jonka jälkeen maahanmuutto Suomeen vilkastui merkittävästi. Väestön moninaistumisesta huolimatta, Suomessa on ollut pitkään hyvin niukasti tietoa ulkomaalaistaustaisen väestön terveydestä ja hyvinvoinnista.

Vuonna 2010 käynnistettiin Suomen ensimmäinen, ja toistaiseksi ainut, ulkomaalaistaustaiselle väestölle kohdennettu terveystarkastustutkimus, jossa otettiin myös verinäytteitä kroonisten sairauksien seulontaa ja seurantaa varten (4). 
Maahanmuuttajien terveys- ja hyvinvointitutkimukseen kutsuttiin venäläis-, somalialais- ja kurditaustaisia aikuisia. Tutkimus tuotti laaja-alaista tietoa kolmen suuren väestöryhmän mielenterveydestä, toimintakyvystä, terveyspalveluiden käytöstä, kroonisten sairauksien esiintyvyydestä ja näiden riskitekijöistä verrattuna Suomen koko väestöön.

Väitöskirjatutkimuksessani tarkastelin sydänja verisuonitautien riskitekijöitä venäläis-, somalialais- ja kurditaustaisessa väestössä Suomessa (5). Tutkitut riskitekijät lisäävät myös muiden kroonisten sairauksien, kuten syöpien ja muistisairauksien, riskiä.

Väestön moninaistuminen muuttaa koko väestön terveysprofiilia. Tutkimuksessani havaitsin merkittäviä eroja venäläis-, somalialais- ja kurditaustaisen väestön sydän- ja verisuonitautien riskiprofiilissa verrattuna Suomen koko väestöön. Tulokset osoittavat, että ulkomaalaistaustaisen väestön terveydenseuranta tulisi integroida selkeämmin osaksi koko väestön terveydenseurantaa. Tämä voidaan käytännössä toteuttaa esimerkiksi sisällyttämällä ulkomaalaistaustaisen väestön lisäotos väestön terveystarkastustutkimuksiin. Tutkimusten tuottamaa tietoa tulisi käyttää eri väestöryhmien terveyden edistämisessä sekä heille kohdennettujen terveyspalvelujen suunnittelussa.

Väestötutkimusten avulla saadaan tietoa väestön terveydestä ja sairauksien syntymekanismeista. Tutkimustiedon avulla voidaan myös tuottaa ennusteita sairaus taakasta tulevina vuosina. Tällä hetkellä käytössä olevien sairauksien riskilaskureiden (esim. FINRISKI- ja FINDRISC laskurit) kykyä ennustaa myös ulkomaalaistaustaisen väestön sairastavuusriskiä tulisi arvioida jatkotutkimuksissa.

Terveyden edistämistoimien suunnittelussa tulisi huomioida, että terveyteen vaikuttavat yksilölliset sosiaaliset ja fyysiset altistukset koko elämänkulun ajalta. Altistuminen erilaisille sairausriskeille voi olla hyvinkin erilaista ulkomaalaistaustaisella väestöllä Suomessa syntyneeseen väestöön verrattuna, erityisesti ennen maahanmuuttoa, mutta myös maahanmuuton jälkeen.

Lopuksi on erityisen tärkeää korostaa, että meidän tulisi rikkoa niitä sosiaalisia rakenteita, jotka vahvistavat vallan ja resurssien epätasaarvoista jakautumista eri väestöryhmien välillä.
Terveystiedon saatavuus ja saavutettavuus, sekä yhdenvertaiset mahdollisuudet käyttää tätä tietoa käytännössä, kuuluvat kaikille ulkomaalaistaustasta, koulutustasosta ja toimintakyvystä riippumatta. Kunnes tämä toteutuu, vastuu yksilön ja väestön terveydestä on niillä, joilla on tiedon valta.

\section{LÄHTEET}

(1) United Nations. International Migration Report 2017: Highlights. 2017.

https://doi.org/10.18356/5e2626a2-en

(2) World Health Organization. Report on the health of refugees and migrants in the WHO European Region: no public health without refugee and migrant health. 2018.

https:// doi=10.1.1.464.8077\&rep=rep1\&type=pdf

(3) Ben-Shlomo Y, Kuh D. A life course approach to chronic disease epidemiology: conceptual models, empirical challenges and interdisciplinary perspectives. Int.J.Epidemiol. $2002 \mathrm{Apr} ; 31(2): 285-293$. https://doi.org/10.1093/ije/31.2.285

(4) Castaneda, A., Rask, S., Koponen, P., Mölsä,M. $\&$ Koskinen, S. (toim.) Maahanmuuttajien terveys ja hyvinvointi. Tutkimus venäläis-, somalialais- ja kurditaustaisista Suomessa. Helsinki: Terveyden ja hyvinvoinnin laitos (THL); Raportti 61/2012. http://urn.fi/URN:ISBN:978-952-245-739-4; 2012.

(5) Skogberg N. Cardiovascular risk factors among Russian, Somali and Kurdish origin populations in Finland [Sydän- ja verisuonitautien riskitekijät venäläis-, somalialais- ja kurditaustaisessa väestössä Suomessa] Helsingin yliopisto, Lääketieteellinen tiedekunta, väitöskirja. http://urn.fi/ URN:ISBN:978-951-51-4830-8; 2019.

\section{NAtAlia Skogberg}

FT

Terveyden ja hyvinvoinnin laitos

Terveystieteiden maisteri Natalia Skogbergin väitöskirja Cardiovascular risk factors among Russian, Somali and Kurdish origin populations in Finland (Sydän- ja verisuonitautien riskitekijät venäläis-, somalialais- ja kurditaustaisessa väestössä Suomessa) tarkastettiin Helsingin yliopiston lääketieteellisessä tiedekunnassa 1.2.2019. Vastaväittäjänä toimi professori Charles Agyemang Amsterdamin yliopistosta ja kustoksena professori Ossi Rabkonen Helsingin yliopistosta. 